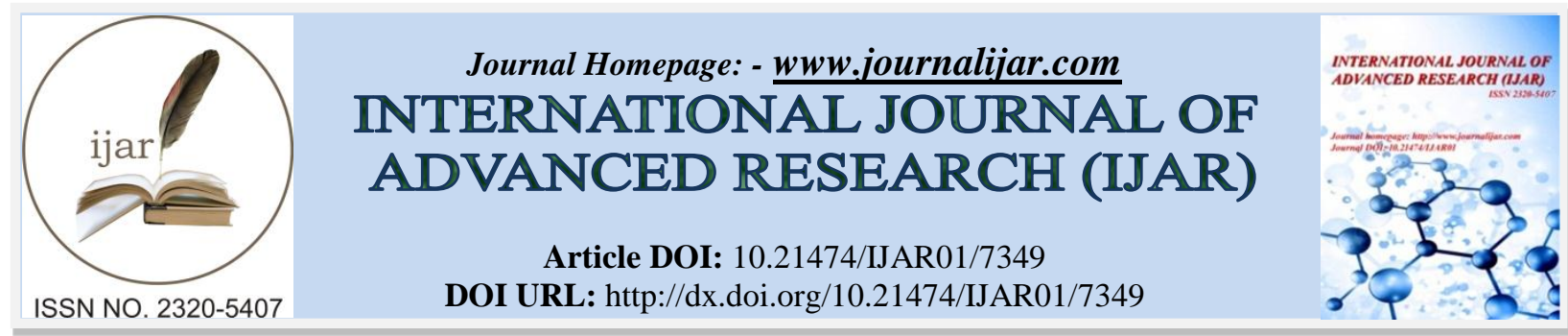

RESEARCH ARTICLE

\title{
A STUDY ON ATTITUDE TOWARDS ICT AND BLENDED LEARNING AMONG B.ED STUDENT'S IN KANCHEEPURAM DISTRICT.
}

B. Jayalakshmi and Dr. N. Prema.

SRM Institute of Teacher Education, Kattankulathur, Tamil Nadu, India.

\section{Manuscript Info}

Manuscript History

Received: 04 May 2018

Final Accepted: 06 June 2018

Published: July 2018

Keywords:-

ICT, Blended Learning, Descriptive

Survey Method.

\begin{abstract}
With the rapid increasing popularity of the computer and internet in recent years, the diversity of learning programs continue to shift and change according to the demand of the society. The purpose of this research project was to study the attitude of B.Ed students towards ICT and Blended learning. To achieve this goal, a descriptive survey method was adopted by using standardized questionnaires. To administrate these questionnaires, 200 students of B.Ed from various colleges were selected as sample by simple random sampling method. Statistical analysis has been made and the result shows that there is a significant difference found between male and female students in attitude towards ICT, but not for Blended Learning. And also result shows that there is no significant differences exist between the students aged below and above 25 in their attitude towards ICT and Blended Learning.
\end{abstract}

Copy Right, IJAR, 2018,. All rights reserved.

\section{Introduction:-}

We are living in the world of Science and technology and it is considered as the fastest vehicle today which is driving the human mankind to the advancement in their respective field. The term computer originated from the word compute or calculate.ICT encompasses both internet enabled sphere as well as the mobile one powered by wireless networks. The institutes without ICT capabilities are left out of the multiple opportunities and benefits that ICT creates; on the other hand Blended learning is an education program that compiles both online digital media with traditional classroom methods. In this method the physical presence of both teacher and students is mandatory. Blended learning is and education program which may be formal or informal that combine on-line digital media with traditional classroom method. It requires the physical presence of both teacher and student.

In Education the information and communication technology has undergone a tremendous development with the introduction of various courses at the graduate and post graduate level. Introduction of information and communication technology (ICT) provide solutions for various problems faced by a teacher in a real class room situation. Teacher gets more creative ideas by integrating computer in their teaching learning process. The responsibility of the teacher has been strengthening by their soft skills; we could consider ICT skills are major one in the soft skills. So the need of ICT in B.Ed is very vital, so student teacher should have a necessary knowledge about ICT at Bachelor of Education level.

Corresponding Author:- B. Jayalakshmi.

Address:- SRM Institute of Teacher Education, Kattankulathur, Tamil Nadu, India. 


\section{ICT: Definition:-}

ICT, or the information and communication technology is the infrastructure and the component that enable modern computing.

"Information and communication Technology" ICT refers to technology that provide access to Information that provide access to information technology (IT), but focuses primarily on communication technologies. This included the internet, wireless networks, cell phones and other communication medium.

\section{Blended learning Definition:-}

The term Blended learning is generally applied to the practice of using both online and in-person learning experiences when teaching students. Blended learning is a method which combines both online and classroom learning activities in the presence of the mentor.

\section{Models of Blended Learning:-}

1. Face to Face driver

2. Rotation

3. Flex

4. Online Lab

5. Self Blend

6. Online Driver

Methods, Samples And Sampling Techniques:-

A descriptive survey method was adopted to collect relevant data from the students. For this purpose two questionnaires have been prepared to measure the attitude towards ICT and Blended Learning separately by the investigator with the help of Guide. Both the questionnaires were standardized for using data collection process. The reliability values were found to be 0.77 and 0.79 respectively. There are 200 students of B.Ed from various colleges located in Kancheepuram District were selected as sample by adopting simple random sampling method to administrate these questionnaires.

\section{Objectives Of The Study:-}

1. To find out the difference in the means scores of attitude towards ICT and Blended Learning among B.Ed student's based on

2. Gender (Boy/Girl)

3. Age (Below 25 years / Above 25 years)

\section{Hypotheses:-}

There is no significant difference in the mean scores of attitude towards ICT among B.Ed student's with respect to

1. Gender.

2. Age

There is no significant difference in the mean scores of attitude towards Blended Learning among B.Ed student's with respect to.

1. Gender.

2. Age

Statistical analysis:-

Table no.1:-showing the critical ratio for ict based on gender.

\begin{tabular}{|l|l|l|l|l|l|l|}
\hline Variables & Gender & Number & Mean & SD & Calculated 't' Value & Remarks \\
\hline \multirow{2}{*}{ ICT } & Male & 24 & 68.3 & 6.61 & 1.89 & NS \\
\cline { 2 - 5 } & Female & 176 & 71.53 & 8.03 & & \\
\hline
\end{tabular}

From the above table (1) it is found that the calculated' $t$ ' value (1.89) is lesser than the table value (1.96) at 5\% level of significance. Thus there is no significant difference in the mean scores of attitude towards ICT of B.Ed student's with respect to Gender. Hence the framed null hypothesis is accepted. 
Table no.2:-Showing the critical ratio for ict based on age.

\begin{tabular}{|l|l|l|l|l|l|l|}
\hline Variables & Age & Number & Mean & SD & Calculated 't' Value & Remarks \\
\hline \multirow{2}{*}{ ICT } & Below 25 & 87 & 71.94 & 7.68 & 1.23 & NS \\
\cline { 2 - 7 } & Above 25 & 113 & 70.54 & 8.10 & & \\
\hline
\end{tabular}

From the above table (2) it is found that the calculated ' $t$ ' value (1.23) is lesser than the table value (1.96) at $5 \%$ level of significance. Thus there is no significant difference in the mean scores of attitude towards ICT of B.Ed student's with respect to Age. Hence the framed null hypothesis is accepted.

Table no.3:-Showing the critical ratio for blended learning based on gender.

\begin{tabular}{|l|l|l|l|l|l|l|}
\hline Variables & Gender & Number & Mean & SD & Calculated 't' Value & Remarks \\
\hline \multirow{2}{*}{ BLENDED } & Male & 24 & 71.15 & 6.89 & 0.29 & NS \\
\cline { 2 - 5 } & Female & 176 & 71.56 & 6.98 & & \\
\hline
\end{tabular}

From the above table (3) it is found that the calculated' $t$ ' value (0.29) is lesser than the table value (1.96) at $5 \%$ level of significance. Thus there is no significant difference in the mean scores of attitude towards BLENDED LEARNING of B.Ed student's with respect to Gender. Hence the framed null hypothesis is accepted.

Table no.4:-Showing The Critical Ratio For Blended Learning Based On Age.

\begin{tabular}{|l|l|l|l|l|l|l|}
\hline Variables & Age & Number & Mean & Sd & Calculated 't' value & Remarks \\
\hline \multirow{2}{*}{$\begin{array}{l}\text { Blended } \\
\text { learning }\end{array}$} & Below 25 & 87 & 72.08 & 7.05 & 1.03 & Ns \\
\cline { 2 - 5 } & Above 25 & 113 & 71.05 & 6.89 & & \\
\hline
\end{tabular}

From the above table (4) it is found that the calculated ' $t$ ' value (1.03) is lesser than the table value (1.96) at $5 \%$ level of significance. Thus there is no significant difference in the mean scores of attitude towards BLENDED LEARNING of B.Ed student's with respect to Age. Hence the framed null hypothesis is accepted.

\section{Conclusion:-}

The mean score of female student teachers is more than male student teacher on both ICT and Blended Learning. The student teacher of age below 25 years is having more attitudes towards ICT and Blended Learning when compared to the student teacher of age above 25 years. Even though the attitude of student teachers on ICT and Blended Learning gives us some satisfaction, we understood that it is not enough. The teacher educator should create more awareness on ICT and Blended Learning among student teachers. The government may give a little more attention to include the ICT and Blended Learning in the curriculum of teacher education.

\section{Suggestion For Further Studies}

1. Similar study could be carried out in other regions also.

2. Role of ICT and Blended Learning, and practice of ICT and Blended Learning also could be analyzed.

3. Practice of ICT and Blended Learning also could be studied

4. Effectiveness of ICT and Blended Learning could be measured among students.

\section{References:-}

1. Dr.Ela Goyal (2015) Effectiveness of Blended Learning in private Indian business school teaching niche programs Volume 5, Issue 2.

2. Bopelo Boitshwarelo (2009) Exploring Blended Learning for science teacher professional development in a African context Volume 10, Number 4, ISSN: 1492-3831.

3. Albert Sangra (2010) the role of information and communication technologies in improving teaching and learning processes in primary and secondary schools Volume 18, Issue 3. 